\title{
Foreign News as Cultural Expression: Media, Perspective, and Consciousness
}

\author{
Takuya Sakurai, ${ }^{1, *}$ \\ ${ }^{1}$ Tokyo Denki University, 5 Senju-asahi-cho, Adachi, Tokyo 1208551, Japan
}

\begin{abstract}
This paper attempts to challenge our dualistic understanding of foreign news and to discuss it as a cultural expression in terms of different structures of consciousness as well as different types of media. Previous foreign news studies seldom explain what foreign news is and how we experience it, and leave what assumptions and presuppositions constitute our understandings of foreign news unanswered. In order to unfold what essentially constitutes foreign news and how it comes to appear to human consciousness, hence, this paper reviews the literature of foreign news and seeks to explain foreign news as a cultural expression.
\end{abstract}

\section{Introduction}

Whenever new media emerge, presentations of foreign news have been in transition. Not only are the forms of foreign-news reportage being changed, but also, more important, the experiences of foreign countries reported are ever being in change. Meaning of foreign news is processed on the basis of contexts bounded multiplicity, including cultural, social, and historical constitution that influences audiences' particular identities or consciousness in processing mediated messages. Different media convey different foreign news in terms of how news stories are packaged in a form of reportage. McLuhan's [1] statement "the medium is the message" might be partly right. However, it is a little too simple to explain the medium power in foreign news. The historical and cultural contexts also give foreign news the differences. Foreign news cannot be simply a medium form of reportage of what is happening in foreign countries; rather, it is reported and consumed in relation to audiences' identities and images of what their country is. In this sense, foreign news can be seen as what Pilotta [2] calls "analogical relatedness." With this analogical relatedness, audiences can be interchangeable and transformative to the media, and they can be united as a group of audiences.

What we categorize into foreign news is relatively a recent formalized type of foreign experiences. In the perspectival sense, foreign news is formed to meet the demand of a rational/mental explanation on foreign events or countries. Although such inventions as telegraphs, television, and the Internet are making foreign news speedier and timely ever than before, reflecting the desires audiences seek in foreign news, perceptivity only allows us to see the history of foreign news in a deterministic manner. Because foreign news has ever since reported in the modern professional forms, the shift of main medium of foreign

\footnotetext{
* Corresponding author: tsakurai@cck.dendai.ac.jp
} 
news from newspaper to television and the Internet reflects what Jean Gebser [3] calls "temporal anxiety," a modern human condition. As Gebser [3] and Lewis Mumford [4] claims, the shift is rather discontinuous and mutational. Foreign news has its own meanings to be reported in different media in different histories and cultures.

Foreign news is a culturally expressive form that allows audiences to find their identities and values in what foreign countries are reported through what channel. Different cultural horizons explore different meanings of foreign news. The horizons lead to a variety of interpretations of the same phenomenon. Differences are perspectives [5]. Differentiating themselves from others are the emerging individual identities [6]. While different horizons are struggling for discursive truth, foreign news is always already being redefined. While post-structuralism focuses on discourse in the metaphysical and linguistic-orientation, Gebser [3] deals with discourse as a "cultural expression," making it free from the articulation of psycho-cultural orientation.

Different values manifested in different media signify underlying differences in a cultural logic, though which some values are predominated over the others. The cultural logic cannot be reduced to any binary opposition or quantification; rather, it is a form with which people can make sense out of what they experience. Gebser [3] calls this logic a "structure of consciousness." People cannot experience anything without their own cultural forms. What they express in their cultural artifacts such as foreign news is a form of how they make sense of the world. All cultures contain these structures of consciousness, but one structure is predominant over the others, and the uniqueness is manifested in their cultural expressions.

Previous studies have attempted to exclusively define foreign news in either behavioristic or political-economic terms. Such an approach is more descriptive than explanatory. In order to grasp foreign news as a form of cultural expression and to explain what foreign news is in terms of our experiences of it, this study attempts to provide a new avenue to illustrate what foreign news is. Based on the idea of perspective, we unfold what constitutes foreign news and how it comes to appear into human consciousness. For the reasons, we review the literature of foreign news, and then seek to explain foreign news as a cultural expression.

\section{Foreign news studies: a review of the literature}

In the realm of communication research, especially in journalism and mass communication, foreign/international news has become an independent field of study. International communication scholars see foreign news from the viewpoint of a worldinformation order and attempt to unveil the Anglo-American dominance over the flow of foreign news and the imbalances between Western developed and non-Western developing countries [7-8]. Media effect studies pay attention to the processes of how foreign news shapes our view of the world [9]. The studies analyze how journalists disseminate international realities and how the audiences make sense of the disseminated realities. Furthermore, the so-called critical studies deal with international news as an ideological product maintaining the status quo [10]. They consider that the news media internalize and legitimize the government's foreign policies within a presentation of international news.

\subsection{International News Flow Studies}

International communication studies examine international news since the inception of the New World Information and Communication Order (NWICO) in the late 1960s [11]. Against the backdrop of the United Nations Educational Science and Cultural Organization (UNESCO), the studies have begun to indicate that the structure of international news flow 
is imbalanced, and that news from developing countries was often biased and misrepresented [8]. A great number of studies have investigated the determinants of international news flow, especially since Scandinavian scholars such as Galtung and Ruge [12] and Ostgaard [13] proposed theoretical foundations of international news flow. The studies propose various factors influencing international news flow and attempted to identify what the best factors are to predict the news flow. The structural theory of international news flow points out that international news we are exposed to is far from a direct reflection of international reality. International news is selected, edited, and deleted through a multitude process of the news media. It also addresses that international news flow is quantitatively imbalanced between Western industrialized and the Third World developing countries, while revealing the Anglo-American dominance of information flow in the world.

International news flow is a major means of information exchange. Since the studies on the structure of international news hardly provide a systematic analysis of a whole-world picture of international news flow, some studies employ the world-system school in order to figure out a global-interaction system that is structured into a center-peripheral relationship. Based on the world-system theory, these studies attempt to identify the structure and process of international news flow within the context of the global network. The world-system theory is an extension of the dependency theory. The dependency theory captures the global system at a two-tier level with the Western developed countries at the center and the rest of the world at the periphery [14]. In his framework, Wallerstein [15] sees the world as a global system in which countries are interdependently linked within the capitalist system, locating countries in the three interactive spheres or zones of cultural, economic, social, and political relations: core, semi periphery, and periphery [14].

The studies employing the world-system theory show a clearer picture of dependency relations with international news flow in a larger structure of international communication. Especially in the age of information technology, the structure of international communication in which countries are located could be a better indicator than their geographical locations. At the same time, however, the growth of global communication systems has brought the emergence of transnational media corporations [8]. Today, these media giants themselves might have the power to set up their own structures of international news flow beyond the boundary of nation-states, while the studies [7-16] employ nation-states as the units of analysis. In this sense, since one of the main premises of the world-system theory is that dependency causes underdevelopment on the nation-state level, their findings may be limited to the extant frameworks of dependency, ignoring the impact of global media corporation such as CNN and Star-TV. Furthermore, the worldsystem theory, as Chang [7] points out, provides little exploration on "whether there is a casual or nonlinear relationship in the news flow" (p. 557). Above all, the "dependency" relationship shows the dynamics of international news flow in a larger formation; however, it leaves the complexity of news industries and the nature of international news unanswered.

\subsection{Media Effect Studies}

Media effect studies attempt to analyze international news, paying attentions to news media's contributions to the constructed meanings within a society $[17,18,19]$. The theories focusing on the processes through which our views of the world are shaped by the mass media have strong impacts on the ways of studying foreign news. These studies see international news as a social artifact constructing a social reality rather than a mirror of reality and support the notion that international news is framed in particular ways by journalistic practices and ideological beliefs. 
Public opinion is believed as one of the major factors that affect foreign policy. Since most people do not have personal knowledge of foreign events, the agenda-setting effect of foreign news is believed to be stronger than that of domestic news. Salwen and Matera [20], for example, found the correlation between foreign news coverage and public opinion to demonstrate agenda-setting effects on international news. Cohen [21] also argues that international news could possibly cause changes of foreign policies and international relations. Thus, these scholars have found that international news coverage is often consistent with the national foreign policies. With regard to the possible effects on coverage on foreign policies, the agenda-setting theory plays an important role in international news studies. Scheufele [22], however, argues that there are two main constraints preventing agenda setting from being called a theory: the lack of inferring causal relations and the ambiguous criterion of measuring of perceptions of issue importance. Especially, the latter constraint becomes a weakness of second-level agenda setting in a comparison with framing. By contrast, "framing influences how audiences think about issues, not by making aspects of the issue more salient, but by invoking interpretive schemas that influence the interpretation of incoming information" [22], p. 309.

\subsection{Critical Studies}

Critical scholars see foreign news as a social and ideological belief. This perspective considers that the news media support the status quo, especially in cases of international conflicts and any challenges from outside the power. News studies focusing on media's ideological roles rely largely on Antonio Gramsci's idea of hegemony, which refers to the predominance of one social class over others [23]. Hegemony tends to be explained with the three key dimensions: common sense, process, and system. Hall [19] explores this view of hegemony to "a web of meaning" and "a terrain of ideology." The idea of hegemony allows researchers to see the news media as "a site for ideological and cultural struggle" [24], p. 80.

The hegemonic ideology shapes the production of news and the news media are seen as part of the process of constructing an accepted symbolic reality. Since the news media are seen as part of the dominant value system, international news reinforces the value of national unity [25]. These studies consider the role of the news media as maintaining the status quo and characterize foreign news as tied to home country's ideology. For example, the studies examining the coverage of social movements show how the news media portrayed the movements and how they delegitimized those who we are outside the dominant groups [18-9]. Thus, the studies employing the hegemony thesis attempt to ask large and important questions about the role of foreign news in a society, and they show us some critical views of how our perceptions are framed hegemonically by the news media.

However, there is a lack of empirical evidence to support these identified roles of the new media [26]. Along with the empirical shortcomings, Altheide [27] also argues that the hegemony thesis fails seeing the contradictions within news messages and its contradictory social effects. Altheide continues to claim that although hegemony is easily used as an interpretive framework for news studies, the news media's characteristics of legitimizing and maintaining the status quo, which the hegemony thesis illustrates, is one-way and arbitrary. As a result, these studies fail examining the complicated interactions between audiences and media texts. This interaction is rather complicated because audiences' interpretations of media contents rely largely on their own identities.

\section{Discussion}

As seen above, foreign news studies have been conducted not only with a number of 
theoretical and methodological bases, but also with a variety of contexts; however, these studies seldom explain how foreign news is interpreted and consumed. All the three schools reviewed above have attempted to exclusively define foreign news in either behavioristic or political-economic terms. Such an approach is more descriptive than explanatory. The following section discusses foreign news as a form of cultural expression and unfolds what constitutes foreign news and how it comes to appear into human consciousness.

\subsection{Foreign News as a Cultural Expression}

The idea of cultural expression is concerned with how discourses are manifested in human consciousness. Gebser [3] articulates that the significance of discourse varies across cultures and that cultural expression provides us with an assessment of how facts and artifacts are incorporated into a discourse. Modern discourse is a form of rationalization, in which signifiers and signified are arbitrarily integrated in the technological/rational milieu. With newspapers, foreign countries are transformed into a modern form of discourse. It has a strong impact on the way people understand foreign countries. Foreign experiences are reduced to perceptivity. The perspectival foreign experience is not only manifested in the modern and rational awareness, but also is a reduced form of knowledge. This transformation of foreign knowledge means that journalism has become institutionalized and individualized [28-29]. News has also become "individualizing activities" and began to be read individually. This perspectival domination over magic/mythical ways of interaction with foreign countries indicates that foreign news becomes "my" story. You can choose some foreign news over others based on your identities and interests. Institutions have also sought to be professionalized as journalism and formalized foreign news into a certain type of discourse [29].

Along with newspaper, television further promotes the perspectival consciousness in foreign news. Kramer contends [30], "Television fosters this process of shifting the sign from being symbolic to being signaled via repetition and false presence-pseudo nature/truth" (pp. 258-259). People are dissociated from the real and extended themselves to what they see and what they image. They become less emotional from their existences. In the perspectival world, human consciousness is dominated by such dichotomous relationships as subject/object and body/mind. Foreign countries emerge in that consciousness as objects of our country. Our country and foreign countries no longer appear complementarily; rather, foreign countries are reduced to others, not "us." The more rationalized foreign news is the more accuracy and precision it requires.

\subsection{Foreign News as an Integrating Interpretation}

Perspective is a rational form of how we make sense of the world. Whereas there are no points of view in the magic and mythical structures of consciousness, a point of view emerged with the perspectival consciousness. Perspective, however, has to be magic and mythical because people cannot do or invent anything without perspective. While foreign news is a form of perspectival consciousness, a perspectival form always contains magic and mythical elements [3]. Magic and myth provide human beings with the fundamental power and connection to something foreign.

Magic is the most fundamental source of power to make something unimaginable imaginable and unidentifiable identifiable. Magic manifestation is the efficacy of not cause, but "making" (Mickunas 1972, p. 183). Magic's mah(g) has the same root as "make," "machine," "mechanism," and "man," which refers to power in Indo-European language $[3,5,6]$ Foreign news is a way of revealing our being-in-the-world. This is the power of "making." It not only makes us available to locate in the world, but also makes foreign 
countries available to interpret with our identifications. Calling television "a technological expression of logocentrism," Kramer [31] claims, "broadcasting is a civilizational expression of the magic impulse in humankind" (p. 35).

The mythical structure is audio-oriented. The word "mythos" means "to speak, say, instruct" [32], (p. 181). Gebser [3] points out the connection between the English word mouth and the Greek mythos. The "mythos" root is also related to the Greek myein, which refers to close oneself [32]. To muse in the mythic structure does not mean thinking in the perspectival sense; rather it implies "belonging" and "thanking." Although this sound/mute might be opposite in the perspectival sense, the relation is rather complementary in the mythical structure. The mythical consciousness serves a basis of providing the hermeneutical foundations of human communication such as comprehension, understanding, interpretation, and translation of foreign countries.

The mythic consciousness also involves imagination: imago, Latin "image" [3]. International images elicit emotional responses on a mythic level like flags, national anthems, and totemic animals. Kramer [30] claims, "Reification of television images is facilitated by the Western bias of logocentrism (p. 257), a cultural bias that assumes that the truth is what we see [31]. Newspaper is also being a logocentric medium, co-existing with television and the Internet. In order to attract television-generation audiences, more visualcentered layouts and story constructions are required in the newspaper. USA Today is a good example to succeed in capturing this trend. Kramer, furthermore, phenomenologically investigated international images, and contends, "International images are deeply rooted in the doxic beliefs in worlds 'out there,' not metaphysically, but geographically, historically and culturally" [30], p. 252.

Foreign news provides the images of foreign countries the way they appear in audience's consciousness. All of the constituents of the images on foreign countries are part of the natural fact-world [30]. However, the images do not necessarily correspond to anything actual; rather, they are the reflections and manifestations of the structure of consciousness as to how meanings and significations are manifested. Images of foreign countries exist the way one believes them to be; therefore, one understands presuppositionally what foreign countries are in accordance with his/her images of them. In order to bracket our natural attitude of imaginary countries, thus, we need a reflective attitude toward the foreign images in the doxic awareness.

\section{Summary}

In sum, the present study has attempted to challenge the perspective view of foreign news and to explore it as a cultural expression. As discussed above, foreign news is not just about what is happening in foreign countries; rather, it is about how we interpret ourselves through foreign countries. Cultural expression intends to be theoretical and explanatory unlike most instrumental and prescriptive communication theories. As opposed to a stimulireact, process-orientation view, it points out that communication is multidimensional rather than unidimensional, and meanings exchanged in communication are ever-presently creative rather than transmission. Cultural expression thus illuminates foreign news as a cultural manifestation as to how we make sense of a given discourse within our cultural milieu. Ways of understanding foreign news reveal a particular belonging to a certain cultural milieu, and cultural expression provides us with a critical means of unfolding what creates and sustains our perspectival understanding of foreign news. 


\section{References}

1. M. McLuhan, The medium is the massage. (Random House, New York, 1967).

2. J.J. Pilotta, Media power working over the body: An application of Gebser to popular culture. Consciousness and culture: An introduction to the thought of Jean Gebser, (Westport, Greenwood, 1992)

3. J. Gebser, N. Barstad, A. Mickunas, The ever-present origin 1 (Ohio University Press, Athens, 1985).

4. L. Mumford, Technics and civilization. (Harcourt, Brace \& World. Orlando, 1963)

5. E.M. Kramer, Modern/postmodern: Off the beaten path of antimodernism. (Westport, Praeger, 1997)

6. E.M. Kramer, Dimensional accrual and dissociation: An introduction. In J. Grace \& E. M. Kramer (Eds.), Communication, comparative cultures, and civilizations $\mathbf{3}$ (Hampton, New York, 2013)

7. T. Chang, Communication Research, 25, 5 (1998)

8. R.L. Stevenson, Journalism Quarterly, 69, 3 (1992)

9. P.J. Shoemaker, S.D. Reese, Mediating the message: Theories of influences on mass media content. (Longman. New York, 1991)

10. C. Lee, J.M. Chan, Z. Pan, C.Y.K. So, Global media spectacle: News war over Hong Kong. (State University of New York Press, Albany, 2002)

11. M. Masmoudi, Journal of Communication, 29, 2 (1979)

12. J. Galtung, H. Ruge, Journal of Peace Research, 2 (1965)

13. E. Ostgaard, Journal of Peace Research, 2 (1965)

14. A.Y. So, Social change and development: Modernization, dependency and worldsystem theories, (Sage, CA: Newburg park, 1990)

15. I. Wallerstein, The modern world system. (Academic Press, New York, 1974)

16. K. Kim, G.A. Barnett, Communication Research, 23, 3 (1996)

17. K.M. Carragee, Journalism Monographs, 128 (1991)

18. T. Gitlin, The whole world is watching: Mass media in the making and unmaking of the New Left. (University of California Press, Berkeley, 1980)

19. S. Hall, The rediscovery of 'ideology': Return of the repressed in mass media studies. Culture, society, and the media. (Methuen, New York, 1982)

20. M.B. Salwen, F.R. Matera, Journalism Quarterly, 69, 3 (1992)

21. B.C. Cohen, The press and foreign policy. (Princeton University Press, Princeton, N.J., 1963).

22. D.A. Scheufele, Mass Communication \& Society, 3 (2000)

23. A. Gramsci, Prison notebooks. (International Publishers, New York, 1971)

24. H.A. Park, Journal of Communication, 48 (1998).

25. T. Chang, Shoemaker, P. J., \& Brenlinger, N. Communication Research, 14 (1987)

26. K.M. Carragee, Western Journal of Communication, 57, 3 (1993)

27. D.L. Altheide, Public Opinion Quarterly, 48, 2 (1984).

28. T. Glander, Origins of Mass Communications Research during the American Cold War: Educational Effects and Contemporary Implications. (Lawrence Erlbaum Associates, Mahwah, N.J., 2000)

29. M. Schudson, Origins of the ideal of objectivity in the professions: Studies in the history of American journalism and American law, (Gerland Publishing, New York, 1990)

30. E.M. Kramer, Phenomenology of international images. In Philip Blosser, Eiichi Shimomisse, Lester Embree, \& Hiroshi Kojima (Eds.), Japanese and Western phenomenology. (Kluwer Academic Publisher, Dordrecht, 1993)

31. E.M. Kramer, The origin of television as civilizational expression. In John Deely (Ed.), Semiotics 1990: Sources in semiotics. (University Press of America, Lanham, M.D, 1993) 
32. Mickunas, Algis. Civilizations as structures of consciousness. Main Currents in Modern Thought, 29, 5 (1972) 